\title{
The Antidepressant Effects of an mGlu2/3 Receptor Antagonist and Ketamine Require AMPA Receptor Stimulation in the mPFC and Subsequent Activation of the 5-HT Neurons in the DRN
}

\author{
Kenichi Fukumoto', Michihiko lijima' and Shigeyuki Chaki*, \\ 'Pharmacology I, Pharmacology Laboratories, Taisho Pharmaceutical, Saitama, Japan
}

\begin{abstract}
We have reported the antidepressant effects of both metabotropic glutamate 2/3 (mGlu2/3) receptor antagonists and ketamine in several animal models, and proposed that serotonergic (5-HTergic) transmission is involved in these actions. Given that the projections from the medial prefrontal cortex (mPFC) to the dorsal raphe nucleus (DRN), where the majority of serotonin (5-HT) neurons exist, are reportedly involved in the antidepressant effects, in this study, we investigated using the forced swimming test (FST) of C57BL/6) male mice, the role of 5-HT neurons in the DRN regulated by the mPFC-DRN projections in the antidepressant effects of an mGlu2/3 receptor antagonist, LY34I 495, and ketamine. Following systemic administration/microinjection into the mPFC, both LY34I 495 and ketamine were found to exert antidepressant effects in the FST, and the effects were attenuated by depletion of 5-HT by treatment with an inhibitor of 5-HT synthesis, PCPA. The antidepressant effects of LY34I 495 and ketamine were also blocked by systemic administration/microinjection into the mPFC of an AMPA receptor antagonist, NBQX. Moreover, systemic administration/microinjection into the mPFC of LY34I495 and ketamine significantly increased the c-Fos expression in the 5-HT neurons in the DRN, and the effect of systemic administration of these drugs on the neuronal c-Fos expression was attenuated by microinjection of NBQX into the mPFC. Our findings suggest that activation of 5-HT neurons in the DRN regulated by stimulation of the AMPA receptor in the mPFC may be involved in the antidepressant effects of an mGlu2/3 receptor antagonist and ketamine.

Neuropsychopharmacology (20 I6) 4I, I046-1056; do::I0.1038/npp.2015.233; published online 9 September 2015
\end{abstract}

\section{INTRODUCTION}

Modulation of the glutamatergic system has emerged as an effective approach to treat depression that is represented by ground-breaking findings of a noncompetitive $N$-methyl-D-aspartate (NMDA) receptor antagonist, ketamine. A single injection of ketamine has been reported to yield the rapid and sustained antidepressant effects not only in patients with major depressive disorder but also in patients with treatment-resistant depression (Berman et al, 2000; Ibrahim et al, 2011; Zarate et al, 2006). However, ketamine also has undesirable side effects, such as psychotomimetic/dissociative symptoms and abuse potential (Krystal et al, 2013), that stimulated research activity to investigate the mechanisms underlying its antidepressant effects so that alternatives with fewer side effects may be identified. To date, increases in synaptic protein synthesis

* Correspondence: Dr S Chaki, Pharmacology I, Pharmacology Laboratories, Taisho Pharmaceutical, I-403 Yoshino-cho, Kita-ku, Saitama, Saitama 33 I-9530, Japan, Tel: +8I 48669 308I, Fax: +8I 48652 7254, E-mail: s-chaki@so.taisho.co.jp

Received 29 April 2015; revised I August 2015; accepted 2 August 2015; accepted article preview online 6 August 2015 and thereby spine density have been proposed to mediate the antidepressant effects of ketamine (Li et al, 2010), presumably through stimulation of the $\alpha$-amino-3-hydroxy5-methyl-4-isoxazole propionic acid (AMPA) receptor that leads to the subsequent activation of brain-derived neurotrophic factor (BDNF)/tropomyosin-related kinase B (TrkB)/mammalian target of rapamycin (mTOR) signaling and inhibition of eukaryotic elongation factor 2 kinase (Autry et al, 2011; Krystal et al, 2013; Li et al, 2010).

Among the possible alternatives to ketamine are metabotropic glutamate $2 / 3(\mathrm{mGlu} 2 / 3)$ receptor antagonists. We have demonstrated the antidepressant effects of mGlu2/3 receptor antagonists in several animal models of depression (Chaki et al, 2004; Karasawa et al, 2005; Pałucha-Poniewiera et al, 2010), including a model that is depression refractory to current medications (Koike et al, 2013a). In addition, we and others have found evidence to suggest that mGlu2/3 receptor antagonists share some of the neural and synaptic mechanisms underlying their antidepressant effects with ketamine, such as AMPA receptor stimulation and subsequent activation of the TrkB receptor and $\mathrm{mTOR}$ signalings, that increase the levels of synaptic proteins in the prefrontal cortex (PFC) (Dwyer et al, 2012; Koike et al, 2011a; Koike et al, 2013b; 
Pałucha-Poniewiera et al, 2010). Therefore, like ketamine, $\mathrm{mGlu} 2 / 3$ receptor antagonists may have the potential to exert the rapid and sustained antidepressant effects and, indeed, an mGlu2/3 receptor antagonist has been shown to exert the rapid and sustained antidepressant effects in the chronic unpredictable stress model (Dwyer et al, 2013).

In addition to the involvement of synaptic plasticity, involvement of the serotonergic (5-HTergic) systems as well in the antidepressant effects of an mGlu2/3 receptor antagonist and ketamine has been suggested. We previously reported that mGlu2/3 receptor antagonists increased the firing of the serotonin (5-HT) neurons in the dorsal raphe nucleus (DRN) as well as enhanced the release of 5-HT in the medial PFC (mPFC) through activation of the AMPA receptor (Karasawa et al, 2005; Kawashima et al, 2005). Similarly, ketamine has been reported to increase the release of $5-\mathrm{HT}$ in the $\mathrm{mPFC}$ of rats and $5-\mathrm{HT}_{1 \mathrm{~B}}$ receptor binding in the nucleus accumbens and ventral pallidum of rhesus monkeys, both actions mediated by activation of the AMPA receptor (Nishitani et al, 2014; Yamanaka et al, 2014). Moreover, we recently reported that 5-HTergic transmission was involved in the actions of both an mGlu2/3 receptor antagonist and ketamine in the novelty-suppressed feeding test (NSFT), presumably in an AMPA receptor-dependent manner (Fukumoto et al, 2014). However, the precise neural mechanisms mediating 5-HTergic transmission in the action of both drugs have not yet been investigated.

The 5-HT neurons in the DRN are regulated by neural projections from various brain regions including the PFC (Pollak Dorocic et al, 2014). Recently, it was reported that although selective stimulation, using an optogenetic technique, of the DRN neurons regulated by mPFC projections induced potent antidepressant effects in rats, activation of the entire population of DRN neurons did not induce the antidepressant effects (Warden et al, 2012). Thus, the 5-HTergic systems selectively modulated by the mPFCDRN projections may be involved in the antidepressant effects. This hypothesis was underpinned by the finding that deep brain stimulation (DBS) of the mPFC exerted an antidepressant effect that was abolished by 5-HT depletion (Hamani et al, 2010). Collectively, these findings suggest that activation of a subset of 5-HT neurons in the DRN modulated by $\mathrm{mPFC}$ projections may have an important role in the antidepressant effects of $\mathrm{mGlu} 2 / 3$ receptor antagonists and ketamine.

Therefore, in this study, we first investigated whether mPFC might be involved in the antidepressant effects of an mGlu2/3 antagonist and ketamine using the forced swimming test (FST), and then investigated the role of the 5 -HT neurons in the DRN selectively regulated by $\mathrm{mPFC}$ projections in the antidepressant effects of an mGlu2/3 receptor antagonist and ketamine.

\section{MATERIALS AND METHODS}

\section{Animals and Housing}

Eight- or nine-week-old male C57BL/6J mice (Charles River Laboratories, Yokohama, Japan) were used for all the experiments. The animals were maintained in controlled temperature $\left(23 \pm 3{ }^{\circ} \mathrm{C}\right)$ and humidity $(50 \pm 20 \%)$ conditions under a 12-h light/dark cycle (lights on at $0700 \mathrm{~h}$ ). Food and water were provided ad libitum. All the studies were performed according to the guidelines of the Taisho Pharmaceutical animal care committee and met the Japanese Experimental Animal Research Association standards, as defined in the Guidelines for Animal Experiments (1987).

\section{Drug Administration}

For systemic administration, LY341495 (Tocris Cookson, Bristol, UK) (mGlu2/3 receptor antagonist) was dissolved in 1/15 M phosphate buffer ( $\mathrm{pH}$ 8.0). Ketamine (Veterinary Ketalar 50; Sankyo Yell Pharmaceutical, Tokyo, Japan) (NMDA receptor antagonist) was diluted with saline. Paroxetine hydrochloride (Toronto Research Chemicals, Toronto, ON, Canada) (selective serotonin reuptake inhibitor) was dissolved in distilled water. NBQX (Tocris Cookson) (AMPA receptor antagonist) was suspended in saline. para-Chlorophenylalanine (PCPA; Sigma-Aldrich, St Louis, MO) (5-HT synthesis inhibitor) was suspended in $0.5 \%$ methylcellulose $(0.5 \% \mathrm{MC})$. LY341495 solution and ketamine solution were diluted using Ringer's solution (147 mM NaCl, $4 \mathrm{mM} \mathrm{KCl}$, and $1.2 \mathrm{mM}$ $\mathrm{CaCl}_{2}$ ) before being used for the intracerebral microinjection. NBQX was dissolved in DMSO, and diluted with Ringer's solution before being used for the intracerebral microinjection. LY341495 (0.1, 0.3, 1 , and $3 \mathrm{mg} / \mathrm{kg})$, ketamine $(3,10$, and $30 \mathrm{mg} / \mathrm{kg})$, and paroxetine $(1,3$, and $10 \mathrm{mg} / \mathrm{kg}$ ) were administered intraperitoneally (i.p.) $30 \mathrm{~min}$ or $24 \mathrm{~h}$ before the test. $\operatorname{NBQX}(1,3$, and $10 \mathrm{mg} / \mathrm{kg})$ was administered subcutaneously (s.c.) $35 \mathrm{~min}$ before the test. PCPA $(300 \mathrm{mg} / \mathrm{kg})$ was administered i.p. twice daily (at $0700-1100 \mathrm{~h}$ and $1600-1900 \mathrm{~h}$ ) for 3 consecutive days, and the tests were conducted $18 \mathrm{~h}$ after the final administration. All the drugs were injected at a volume of $10 \mathrm{ml} / \mathrm{kg}$ body weight for the systemic administration experiments. The doses for the systemic administration of LY341495, ketamine, NBQX, and PCPA were selected based on previous reports (Fukumoto et al, 2014; Koike et al, 2013b). The dose for the systemic administration of paroxetine was selected according to the observation in a previous study (Sugimoto et al, 2011). For the intracerebral microinjection experiments, LY341495 (0.003 and $0.03 \mathrm{pmol} / 0.1 \mu \mathrm{l} / \mathrm{side})$ or ketamine $(0.3$ and $3 \mathrm{nmol} / 0.1 \mu \mathrm{l} /$ side $)$ was injected $30 \mathrm{~min}$ or $24 \mathrm{~h}$ before the test, and NBQX (0.01 and 0.03 $\mathrm{nmol} / 0.1 \mu \mathrm{l} /$ side) was injected $35 \mathrm{~min}$ before the test. The doses for the intracerebral microinjection of LY341495, ketamine, and NBQX were selected based on the observations in previous studies (Iijima et al, 2013; López-Gil et al, 2007; López-Gil et al, 2012; Nishitani et al, 2014).

\section{Microinjection}

Each mouse was anesthetized with pentobarbital $(50 \mathrm{mg} / \mathrm{kg}$, i.p.) and fixed to a brain stereotaxic apparatus (Narishige Instruments, Tokyo, Japan). For the injection into the mPFC, the brains were implanted with guide cannulas (Eicom, Kyoto, Japan) bilaterally, so that the tips were positioned near the $\mathrm{mPFC}$ (anteroposterior, $2.0 \mathrm{~mm}$ from bregma; lateral, $\pm 1.4 \mathrm{~mm}$; ventral, $-2.3 \mathrm{~mm}$; angle, $\left.20^{\circ}\right)$. The cannulas were held in place with dental cement. A dummy cannula was inserted into the guide cannula to prevent clogging. Microinjection of LY341495, ketamine, and NBQX 
was performed on day 2 or 3 after the surgery. Before the microinjections, the dummy cannulas were removed from the guide cannula, and a 28-gauge injection cannula, extending $0.5 \mathrm{~mm}$ from the tip of the guide cannula, was inserted. The injection cannula was connected via a Teflon tubing to a microsyringe (Hamilton, Reno, NV) driven by a micro infusion pump (Harvard Apparatus, Holliston, MA). Injections of LY341495, ketamine, and NBQX were performed over $2 \mathrm{~min}$ at the rate of $0.05 \mu \mathrm{l} / \mathrm{min}$. The injection cannulas were left in position for an additional 2 min before being withdrawn. After the behavioral test, Evans blue was infused, followed by preparation of coronal sections to confirm the locations of the cannula tips. The locations of the cannula tips are shown in Figures $2 \mathrm{e}-\mathrm{h}$ and $3 \mathrm{~g}$ and $\mathrm{h}$ and Supplementary Figures S2c and d and S3.

\section{Forced Swimming Test}

The FST was performed by a previously reported method, with some modification (Ago et al, 2013). Although immobility in the FST is a controversial measure of depressive-like behavior, it is a useful screen for compounds that are effective for the treatment of depression. Thus, we used the FST in the present study and evaluated the effects of the compounds by measuring the immobility time of the animals in the test. For the test, the mice were placed in a swim tank for $6 \mathrm{~min}$ on day 1 to induce a state of helplessness, and then placed back in the swim tank for 6 min on day 2 to measure the immobility time. The swimming sessions were conducted by placing the mice in cylinders $(24 \mathrm{~cm}$ height $\times 17 \mathrm{~cm}$ diameter) containing water $\left(25 \pm 1{ }^{\circ} \mathrm{C}\right)$ up to a height of $13 \mathrm{~cm}$, so that the mice could not support themselves by touching the bottom of the tank with their paws. The FST was conducted between 0800 and $1700 \mathrm{~h}$. The water in the cylinders was changed after every trial. Test sessions were videotaped from the front of the cylinders for later scoring by a scorer. The total duration of immobility during a 6-min test session was measured by an observer blinded to the treatment conditions. Immobility was defined as floating in the water without struggling and only making movements necessary to keep the head above the water.

\section{Measurement of the Spontaneous Locomotor Activity}

Mice were housed individually in transparent acrylic cages $(\varphi 30 \mathrm{~cm} \times 30 \mathrm{~cm})$. Each compound was injected at designated time point, and the spontaneous locomotor activities were recorded for $60 \mathrm{~min}$ afterward using a SCANET apparatus (Neuroscience, Tokyo, Japan) placed in a sound-proof box.

\section{Tissue Processing}

Mice were administered LY341495 (0.03 pmol/0.1 $\mu \mathrm{l} / \mathrm{side}$, $1 \mathrm{mg} / \mathrm{kg}$, s.c.) or ketamine $(3 \mathrm{nmol} / 0.1 \mu \mathrm{l} / \mathrm{side}, 30 \mathrm{mg} / \mathrm{kg}$, s.c.) $90 \mathrm{~min}$ before the perfusion, and NBQX $(0.03 \mathrm{nmol} / 0.1 \mu \mathrm{l} /$ side) $95 \mathrm{~min}$ before the perfusion. The administration time of these drugs was selected based on the findings of a previous study (Nowak et al, 2012). Following induction of inhalation anesthesia (Isoflurane; Mylan Pharmaceutical, Tokyo, Japan), the mice were perfused with $0.1 \mathrm{M}$ phosphate- buffered saline (PBS) followed by ice-cold $4 \%$ paraformaldehyde in $0.1 \mathrm{M}$ phosphate buffer ( $\mathrm{pH} 7.4$ ). The brains were removed, post-fixed (overnight), cryoprotected in a $30 \%$ sucrose solution (in PBS), and stored at $4{ }^{\circ} \mathrm{C}$ until they sank. Coronal sections $(2 \mathrm{~mm})$ throughout the DRN (bregma -4.00 to -6.00 ) were embedded in OCT compound (Sakura, Tokyo, Japan) and frozen in liquid nitrogen.

\section{Immunofluorescence Studies}

Cryosections $(40 \mu \mathrm{m})$ at $1: 3(120 \mu \mathrm{m})$ intervals through the DRN between -4.48 and $-4.84 \mathrm{~mm}$ from the bregma (2 serial sections for a region) were prepared. The expression of c-Fos in the 5-HT cell bodies in the DRN was studied by double immunofluorescence. Sections were washed thrice with PBS for 10 min each and blocked with PBS/0.3\% Triton $\mathrm{X}-100 / 5 \%$ donkey serum for $1 \mathrm{~h}$ at room temperature before incubation overnight with rabbit anti-c-Fos antibody $(1: 500$, Abcam, Cambridge, MA) and goat anti-TPH2 antibody $(1: 500, \mathrm{Abcam})$ at $4^{\circ} \mathrm{C}$. After washing, the sections were incubated with the fluorescent 594 donkey anti-rabbit IgG secondary antibody and 488 donkey anti-goat IgG secondary antibody $(1: 200$, Jackson ImmunoResearch Laboratories, West Grove, PA) for $2 \mathrm{~h}$ at room temperature. The sections were then mounted on slides, and coverslipped.

\section{Image Processing and Quantification}

In the DRN, sections were assessed for the number of single 5-HT-positive cells and double-labeled cells for 5-HT and c-Fos using a confocal microscope at a magnification of $\times 40$ (Leica TCS SP5, Leica Microsystems, Wetzlar, Germany); the cells were counted using the ImageJ software (National Institutes of Health, Bethesda, MD) by an observer who was blinded to the experimental treatment allocations of each mouse. Cell counts for a region are based on cell counts from a single brain section from each mouse from each treatment group. There was no significant variation of total number of 5-HT-positive cells within each treatment group. Colocalization of c-Fos immunoreactivity with 5-HT in the cell bodies was confirmed by confocal microscopy at a magnification of $\times 40$.

\section{Statistical Analysis}

The results were expressed as mean \pm SEM. Statistical significance was determined by one-way analysis of variance (ANOVA) or a two-way ANOVA, followed by Dunnett's, Tukey's, or LSD post hoc test for comparing the treated group with the control group and multigroup comparisons, respectively. Statistical differences between any two groups were determined using Student's $t$-test; $p<0.05$ was considered to indicate statistically significant difference.

\section{RESULTS}

Effect of 5-HT Depletion on the Antidepressant Effect of
LY341495, Ketamine, or Paroxetine in the FST

Systemic administration of LY341495 (1 mg/kg i.p.) significantly reduced the immobility time in the FST $(F(3,28)=19.87, p<0.001$; Figure 1a). Systemic administration 

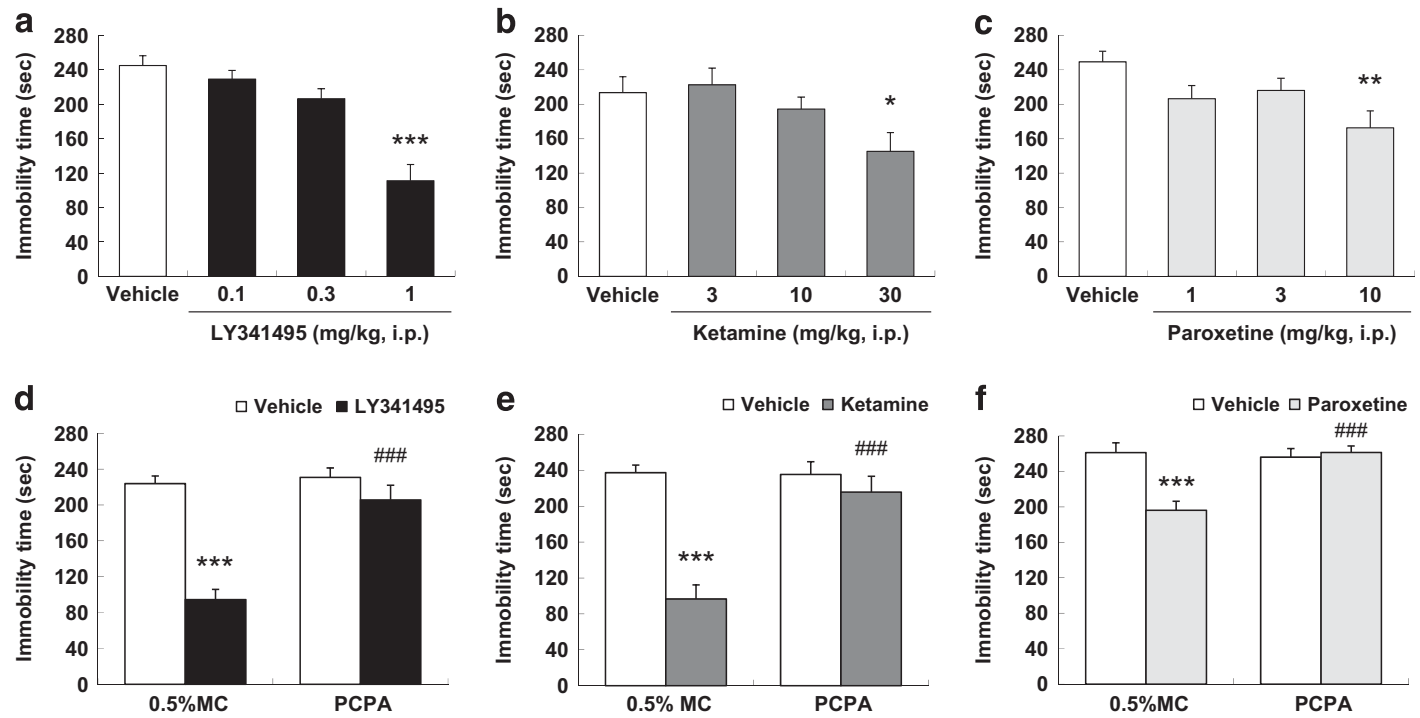

Figure I Effect of 5-HT depletion on the antidepressant effect of LY34I495, ketamine, or paroxetine in the FST. Effect of LY34I495 (a), ketamine (b), or paroxetine (c). LY34I 495 (0.I, 0.3, and I mg/kg i.p.), ketamine (3, I0, and $30 \mathrm{mg} / \mathrm{kg}$ i.p.), or paroxetine (I, 3, and I $0 \mathrm{mg} / \mathrm{kg}$ i.p.) was administered $30 \mathrm{~min}$ before the test. Vehicle = (a): I/I 5 M phosphate buffer ( $\mathrm{pH}$ 8.0), (b): saline, (c): distilled water. Values indicate the mean $\pm S E M((a): n=8,(b): n=8,(c): n=8)$. $* P<0.05, * * p<0.01$, **** $p<0.00$ I compared with each vehicle (Dunnett's test). Effect of 5-HT depletion on the antidepressant effect of LY34I495 (d), ketamine (e), or paroxetine (f). LY34I 495 (I mg/kg i.p.), ketamine $(30 \mathrm{mg} / \mathrm{kg}$ i.p.), or paroxetine (I $0 \mathrm{mg} / \mathrm{kg}$ s.c.) was administered $30 \mathrm{~min}$ before the test. PCPA (300 mg/ $/ \mathrm{kg}$ i.p.) was administered twice daily for 3 consecutive days until the day before the test. Vehicle $=(\mathrm{d})$ : I/I $5 \mathrm{M}$ phosphate buffer ( $\mathrm{pH}$ 8.0), (e): saline, (f): distilled water. Values indicate the mean \pm SEM ((d): $n=10,(e): n=10,(f): n=9-10)$. **** $<0.001$ compared with $0.5 \%$ MC-treated each vehicle, $\# \#$ \# $<0.00$ I compared with 0.5\% MC-treated agents ((d): LY34|495, (e): ketamine, (f): paroxetine) (LSD post hoc test).

of ketamine $(30 \mathrm{mg} / \mathrm{kg}$ i.p.) also significantly reduced the immobility time in the FST $(\mathrm{F}(3,28)=3.45, p<0.05$; Figure $1 \mathrm{~b})$. Furthermore, systemic administration of paroxetine (10 mg/kg i.p.) also significantly reduced the immobility time in the FST $(F(3,28)=4.15, p<0.05$; Figure 1c). The decrease in the immobility time induced by systemic administration of LY341495 (1 mg/kg i.p.) was blocked by pretreatment with PCPA (300 mg/kg i.p. twice daily for 3 days) (LY341495, $\mathrm{F}(1,36)=41.11, p<0.001 ;$ PCPA, $\mathrm{F}(1,36)=24.11, p<0.001$; interaction, $\mathrm{F}(1,36)=18.75, p<0.001$; Figure 1d). Similarly, the decrease in the immobility time induced by systemic administration of ketamine $(30 \mathrm{mg} / \mathrm{kg}$ i.p.) was also blocked by pretreatment with PCPA ( $300 \mathrm{mg} / \mathrm{kg}$ i.p. twice daily for 3 days) (ketamine, $\mathrm{F}(1,36)=30.69, p<0.001$; PCPA, $\mathrm{F}(1,36)=16.35$, $p<0.001$; interaction, $\mathrm{F}(1,36)=17.43, p<0.001$; Figure 1e). Furthermore, the decrease in the immobility time induced by systemic administration of paroxetine $(10 \mathrm{mg} / \mathrm{kg}$ s.c. $)$ was also blocked by pretreatment with PCPA $(300 \mathrm{mg} / \mathrm{kg}$ i.p. twice daily for 3 days) (paroxetine, $\mathrm{F}(1,34)=10.60, p<0.01$; PCPA, $\mathrm{F}(1,34)=9.52 ; \quad p<0.01 ; \quad$ interaction, $\quad \mathrm{F}(1,34)=13.01$, $p<0.001$; Figure 1f), indicating that the present condition is suitable to investigate the involvement of the 5-HTergic transmission in the antidepressant actions. In contrast, systemic administration of PCPA $(300 \mathrm{mg} / \mathrm{kg}$ i.p. twice daily for 3 days) per se had no effect on the immobility time in the FST (Figure 1d-f). Of note, systemic administration of LY341495 (1, $3 \mathrm{mg} / \mathrm{kg}$ i.p.) and ketamine (30 mg/kg i.p.) had no effect on the locomotor activities (LY341495 $(1 \mathrm{mg} / \mathrm{kg}$ ), $\mathrm{F}(1,10)=2.85, p=0.12 ; \mathrm{LY} 341495(3 \mathrm{mg} / \mathrm{kg}), \mathrm{F}(1,10)=1.67$, $p=0.22$; ketamine, $\mathrm{F}(1,10)=1.71, p=0.22$; Supplementary Table S1).

In treatment with LY341495, ketamine, and paroxetine at $24 \mathrm{~h}$ before the test, LY341495 $(3.0 \mathrm{mg} / \mathrm{kg})$ and ketamine
$(30 \mathrm{mg} / \mathrm{kg})$ significantly reduced the immobility time in the FST (LY341495, $F(4,35)=3.29, \quad p<0.05 ; \quad$ ketamine, $\mathrm{F}(4,35)=8.33, p<0.01$; Supplementary Figure S1a and b), whereas paroxetine had no such effect on the immobility time in the FST $(F(3,28)=0.10, p=0.96$; Supplementary Figure S1c). The decrease in the immobility time induced by systemic administration of LY341495 (3 mg/kg i.p.) was blocked by pretreatment with PCPA $(300 \mathrm{mg} / \mathrm{kg}$ i.p. twice daily for 3 days) (LY341495, $\mathrm{F}(1,36)=38.10$, $p<0.001 ;$ PCPA, $\mathrm{F}(1,36)=23.15, p<0.001$; interaction, $\mathrm{F}(1,36)=28.26, p<0.001$; Supplementary Figure S1d). Similarly, the decrease in the immobility time induced by systemic administration of ketamine $(30 \mathrm{mg} / \mathrm{kg}$ i.p.) was also blocked by pretreatment with PCPA $(300 \mathrm{mg} / \mathrm{kg}$ i.p. twice daily for 3 days) (ketamine, $F(1,36)=16.62$, $p<0.01 ;$ PCPA, $\mathrm{F}(1,36)=10.09, p<0.001$; interaction, $\mathrm{F}(1,36)=12.66, p<0.01$; Supplementary Figure S1e). In contrast, administration of PCPA $(300 \mathrm{mg} / \mathrm{kg}$ i.p. twice daily for 3 days) per se had no effect on the immobility time in the FST (Supplementary Figure S1d and e).

\section{Effect of Microinjection of LY341495 or Ketamine into the MPFC in the FST}

Microinjection of LY341495 (0.03 pmol/0.1 $\mu \mathrm{l} / \mathrm{side})$ into the mPFC significantly reduced the immobility time in the FST $(\mathrm{F}(2,21)=14.37, p<0.001$; Figure 2a). Microinjection of ketamine $(3 \mathrm{nmol} / 0.1 \mu \mathrm{l} / \mathrm{side})$ into the $\mathrm{mPFC}$ also significantly reduced the immobility time in the FST $(\mathrm{F}(2,20)=11.65, p<0.001$; Figure $2 \mathrm{~b})$. The decrease in the immobility time induced by microinjection of LY341495 $(0.03 \mathrm{pmol} / 0.1 \mu \mathrm{l} / \mathrm{side})$ into the $\mathrm{mPFC}$ was blocked by pretreatment with PCPA $(300 \mathrm{mg} / \mathrm{kg}$ i.p. twice daily for 

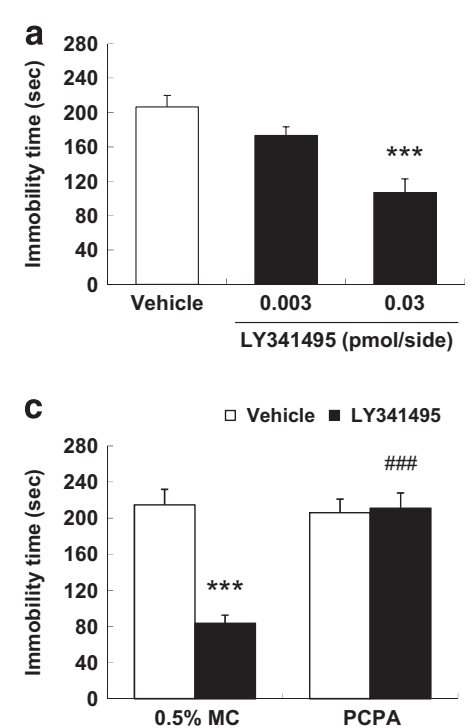

e

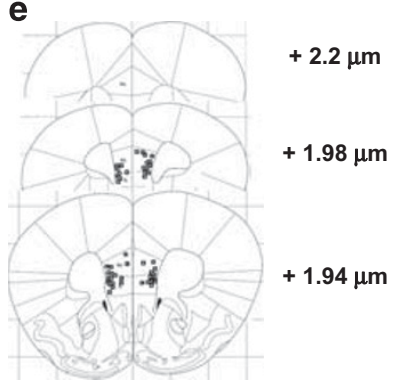

f

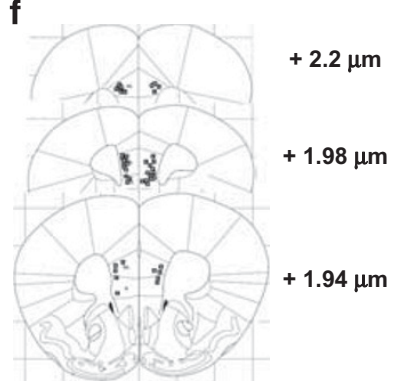

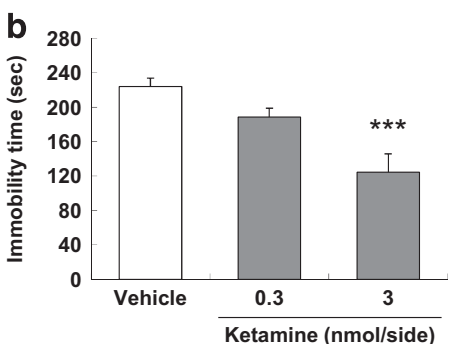

d

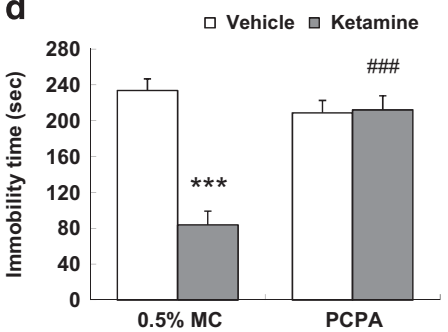

g

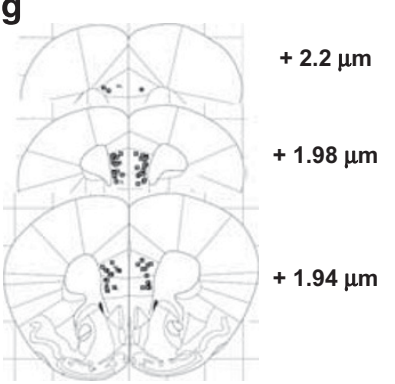

h

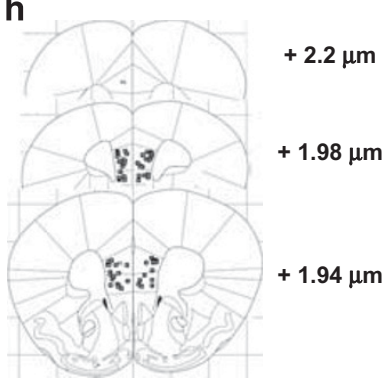

Figure 2 Effect of microinjection of LY34I 495 or ketamine into the mPFC in the FST. Effect of microinjection of LY34I 495 (a) or ketamine (b). LY34 I 495 $(0.003$, and $0.03 \mathrm{pmol} / \mathrm{side})$ or ketamine $(0.3$ and $3 \mathrm{nmol} / \mathrm{side})$ was administered into the $\mathrm{mPFC} 30 \mathrm{~min}$ before the test. Vehicle $=(\mathrm{a}): 0.1 \% \mathrm{I} / \mathrm{I} 5 \mathrm{M}$ phosphate buffer ( $\mathrm{pH}$ 8.0) in Ringer's solution, (b): Ringer's solution. Values indicate the mean $\pm \mathrm{SEM}((\mathrm{a}): n=8,(b): n=7-8)$. $* * * * P<0.00$ I compared with each vehicle (Dunnett's test). Effect of 5-HT depletion on the antidepressant effect of microinjection of LY34I495 (c) or ketamine (d) into the mPFC. LY34I495 $(0.03 \mathrm{pmol} / \mathrm{side})$ or ketamine ( $3 \mathrm{nmol} / \mathrm{side})$ was administered into the $\mathrm{mPFC} 30 \mathrm{~min}$ before the test. PCPA (300 mg/kg i.p.) was administered twice daily for 3 consecutive days until the day before the test. Vehicle $=(\mathrm{c}): 0.1 \% \mathrm{I} / \mathrm{I} 5 \mathrm{M}$ phosphate buffer $(\mathrm{pH}$ 8.0) in Ringer's solution, (d): Ringer's solution. Values indicate the mean \pm SEM ((c): $n=8,(d): n=7-8)$. **** $P<0.00$ I compared with $0.5 \%$ MC-treated each vehicle, ${ }^{\# \# ~} p<0.00$ I compared with $0.5 \%$ MC-treated agents ((c): LY34I495, (d): ketamine) (LSD post hoc test). (e, f, g, h) Location of the microinjection cannula tips in the mPFC included in the analyses of the data illustrated $((e)=(a),(f)=(b),(g)=(c),(h)=(d))$. The line drawings are from Paxinos and Franklin (1997). The numbers to the right are $m m$ from the bregma. The open square represents the location of the microinjection cannula tips.

3 days) (LY341495, $\mathrm{F}(1,28)=18.11, p<0.001 ; \quad \mathrm{PCPA}$, $\mathrm{F}(1,28)=16.02, \quad p<0.001$; interaction, $\mathrm{F}(1,28)=21.10$, $p<0.001$; Figure 2c). The decrease in the immobility time induced by microinjection of ketamine $(3 \mathrm{nmol} / 0.1 \mu \mathrm{l} /$ side $)$ into the mPFC was also blocked by pretreatment with PCPA $(300 \mathrm{mg} / \mathrm{kg}$ i.p. twice daily for 3 days) (ketamine, $\mathrm{F}(1,27)=27.03, p<0.001$; PCPA, $\mathrm{F}(1,27)=13.78, p<0.001$; interaction, $\mathrm{F}(1,27)=27.45, p<0.001$; Figure $2 \mathrm{~d})$. In contrast, PCPA injection ( $300 \mathrm{mg} / \mathrm{kg}$ i.p. twice daily for 3 days) per se had no effect on the immobility time in the FST (Figure 2c and d). Of note, microinjection of LY341495 $(0.03 \mathrm{pmol} / 0.1 \mu \mathrm{l} /$ side $)$ or ketamine $(3 \mathrm{nmol} / 0.1 \mu \mathrm{l} /$ side $)$ into the $\mathrm{mPFC}$ had no effect on the locomotor activities (LY341495, $\mathrm{F}(1,10)<0.01, \quad p=0.97$; ketamine, $\mathrm{F}(1,10)$ $<0.01, p=0.96$; Supplementary Table S1).

We further investigated whether the microinjection of LY341495 and ketamine into the mPFC shows sustained antidepressant effects in the FST. The microinjection of LY341495 (0.03 pmol/0.1 $\mu \mathrm{l} / \mathrm{side})$ or ketamine (3 nmol/0.1 $\mu \mathrm{l} /$ side) into the $\mathrm{mPFC}$ at $24 \mathrm{~h}$ before the test significantly reduced the immobility time in the FST (LY341495, $\mathrm{F}(1,13)=83.88, \quad p<0.001 ; \quad$ ketamine, $\quad \mathrm{F}(1,14)=51.64$, $p<0.001$; Supplementary Figure S2a and b). Figure $2 \mathrm{e}-\mathrm{h}$ and Supplementary Figure S2c and d show the locations of the tips of the microinjection cannulas in the mPFC included in the analysis of the data shown in Figure $2 a-d$ and Supplementary Figures S2a and b, respectively, that were included in the statistical analyses.

\section{Effect of an AMPA Receptor Antagonist on the Antidepressant Effect of LY341495 or Ketamine in the FST}

The decrease in immobility time induced by systemic administration of LY341495 (1 mg/kg i.p.) was blocked by systemic administration of an AMPA receptor antagonist, NBQX $\quad(10 \mathrm{mg} / \mathrm{kg} \quad$ s.c. $) \quad(\mathrm{F}(4,35)=13.14, \quad p<0.001$; Figure 3a). Similarly, the decrease in the immobility time induced by systemic administration of ketamine (30 mg/kg i.p.) was also blocked by systemic administration 


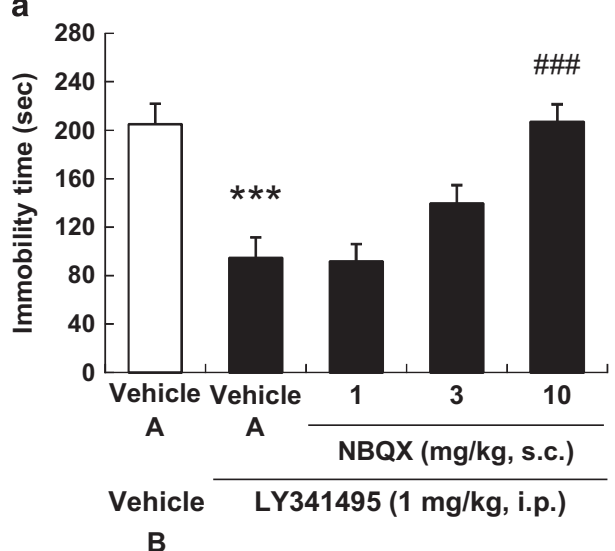

B

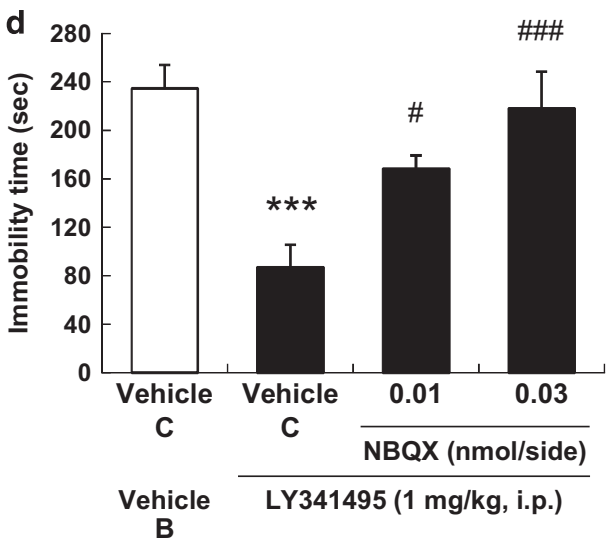

g

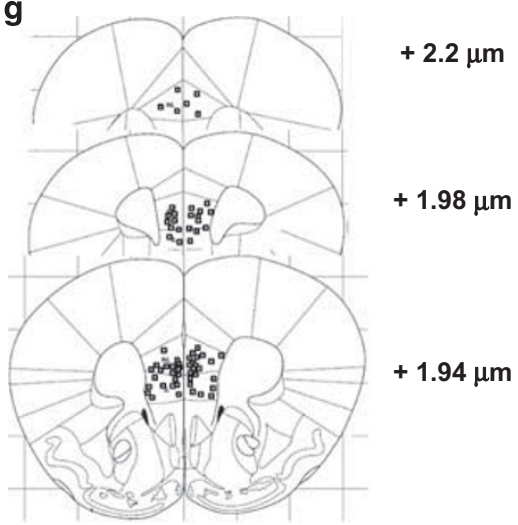

b

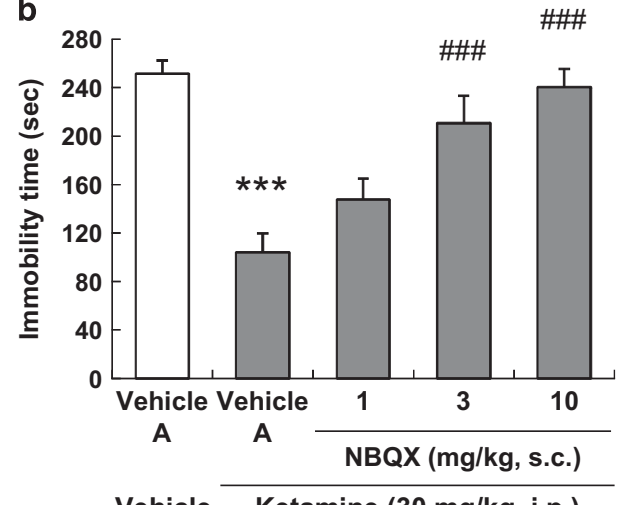

C

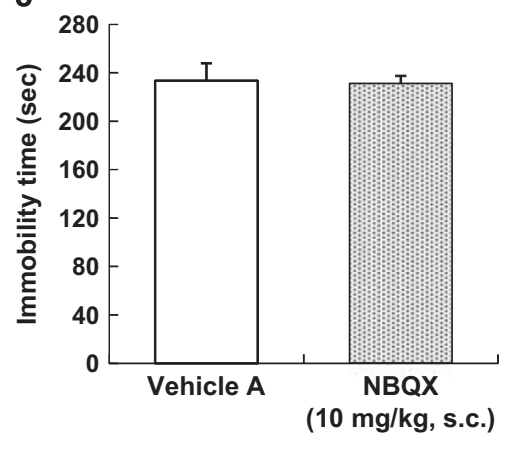

A

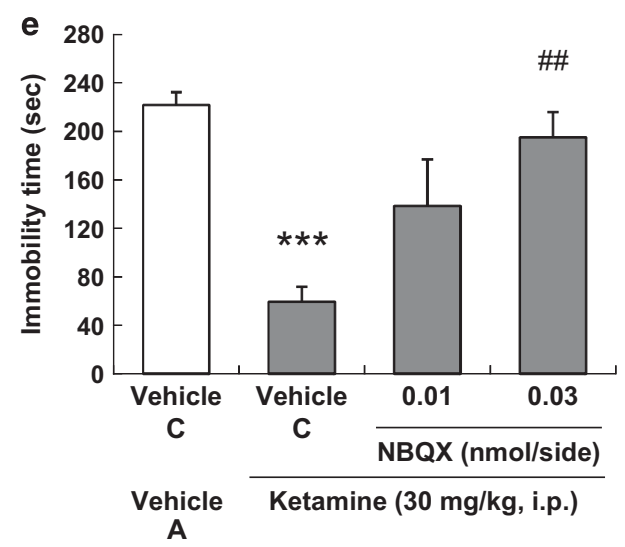

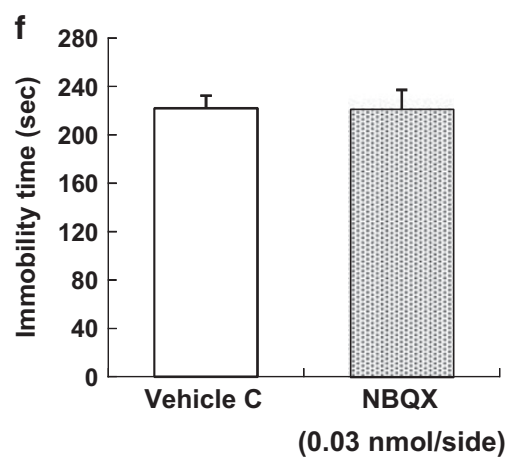

A

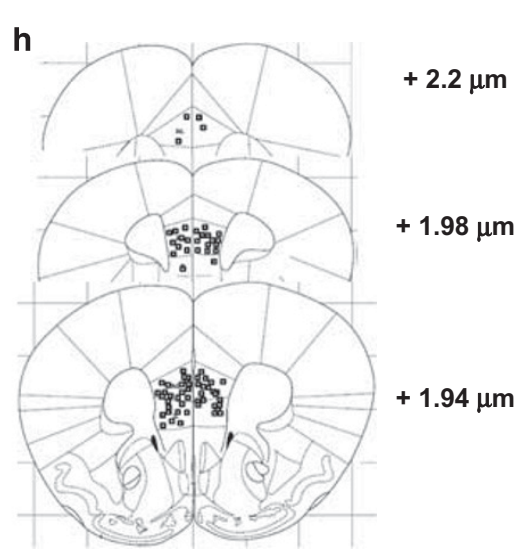

Figure 3 Effect of an AMPA receptor antagonist on the antidepressant effect of LY34I495 or ketamine in the FST. Effect of systemic administration of NBQX. (a) LY34I495 (I mg/kg i.p.) or (b) ketamine (30 mg/kg i.p.) was administered $30 \mathrm{~min}$ before the test, and NBQX (I, 3, and I0 mg/kg s.c.) was administered $35 \mathrm{~min}$ before the test. (c) NBQX (I $0 \mathrm{mg} / \mathrm{kg}$ s.c.) was administered $35 \mathrm{~min}$ before the test. Vehicle A: saline, Vehicle B: I/I 5 M phosphate buffer $(\mathrm{pH}$ 8.0). Values indicate the mean \pm SEM ((a): $n=8,(b): n=7-9,(c): n=8)$. **** $P<0.00$ I compared with vehicle A-treated vehicles ((a): vehicle B, (b): vehicle A), ${ }^{\# \# \#}$ P $<0.00$ I compared with vehicle A-treated agents ((a): LY34I495, (b): ketamine) (Tukey's post hoc test). Effect of microinjection of NBQX into the mPFC. (d) LY34I495 (I mg/kg i.p.) or (e) ketamine (30 mg/kg i.p.) was administered $30 \mathrm{~min}$ before the test, and NBQX (0.0 I and $0.03 \mathrm{nmol} / \mathrm{side})$ was administered into the mPFC 35 min before the test. ( $)$ NBQX $(0.03 \mathrm{nmol} / \mathrm{side})$ was administered into the mPFC 35 min before the test. Vehicle A: saline, Vehicle B: I/I 5 M phosphate buffer ( $\mathrm{pH} 8.0)$, Vehicle C: I0\% DMSO in Ringer's solution. Values indicate the mean \pm SEM ((d): $n=8-9,(e): n=7-8$, $(f): n=7-8)$. (g, h) Location of the microinjection cannula tips in the mPFC included in the analyses of the data illustrated $((\mathrm{g})=(\mathrm{d}),(\mathrm{h})=(\mathrm{e}),(\mathrm{f}))$. The line drawings are from Paxinos and Franklin (1997). The numbers to the right are $\mathrm{mm}$ from the bregma. The open square represents the location of the microinjection cannula tips. ${ }^{*} * * P<0.001$ compared with vehicle C-treated vehicles ((d): vehicle $B$, (e): vehicle A), ${ }^{\#} p<0.05,{ }^{\# \#} p<0.01$, ${ }^{\# \# \#} p<0.00$ I compared with vehicle C-treated agents ((d): LY34I495, (e): ketamine) (Tukey's post hoc test).

of $\mathrm{NBQX}(3,10 \mathrm{mg} / \mathrm{kg}$ s.c. $)(\mathrm{F}(4,35)=14.57, p<0.001$; Figure $3 \mathrm{~b})$. In contrast, systemic administration of NBQX (10 mg/kg s.c.) had no effect on the immobility time in the FST $(\mathrm{F}(1,14)=0.03, p=0.88$; Figure 3c) and the locomotor activities $(\mathrm{F}(1,10)<0.01, p=0.97$; Supplementary Table S1).

The decrease in the immobility time induced by systemic administration of LY341495 ( $1 \mathrm{mg} / \mathrm{kg}$ i.p.) was blocked by 
a
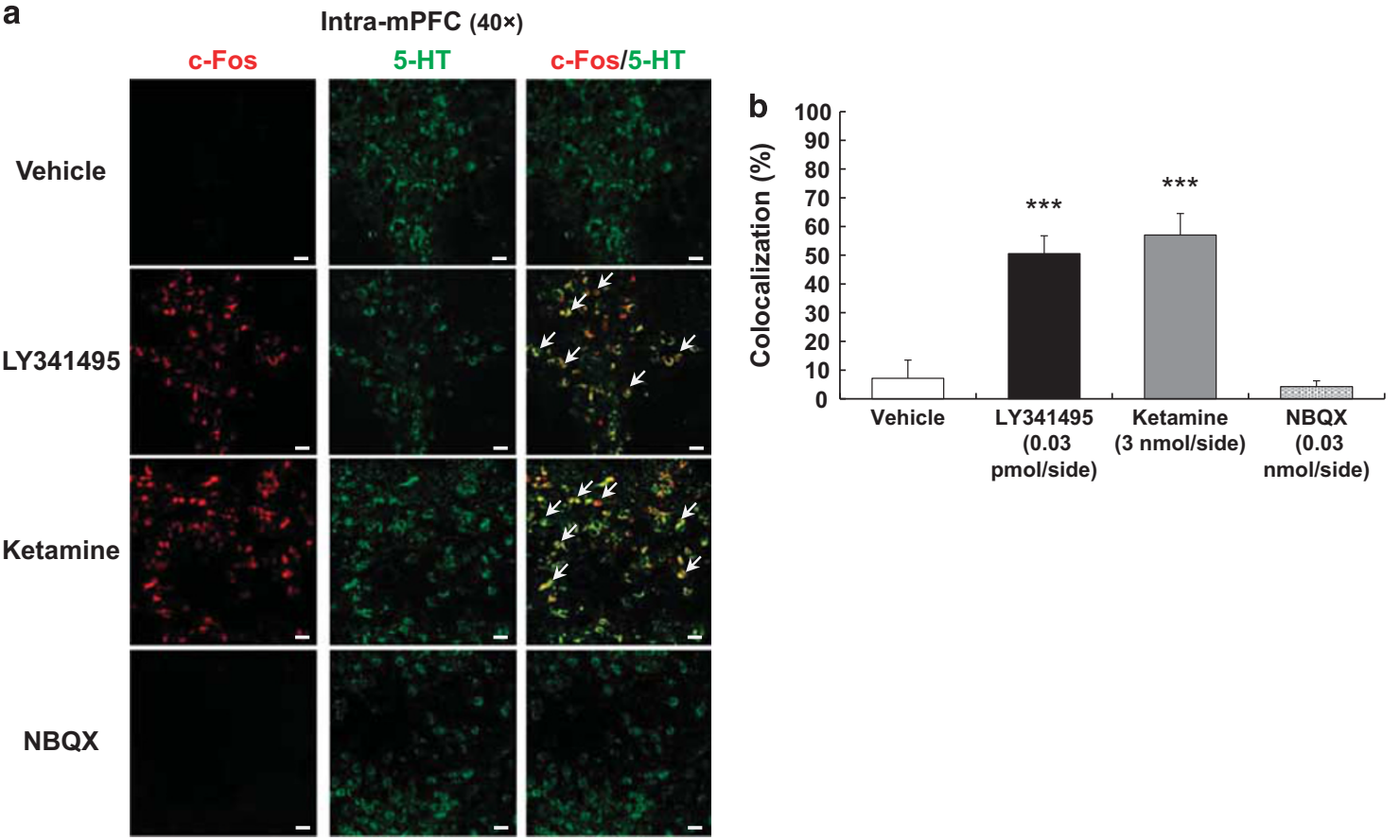

Figure 4 Effect of microinjection of LY34I495 or ketamine on the c-Fos immunoreactivity colocalized with 5-HT neuron cells in the dorsal raphe nucleus. (a) Confocal images of c-Fos (red), 5-HT cells (green), and double (5-HT/c-Fos, colocalization) immunoreactivities in the DRN at around - $4.72 \mathrm{~mm}$ from bregma (Scale bar: (a) $20 \mu \mathrm{m}$ ). Arrows represent the double (5-HT/c-Fos, colocalization) immunoreactivities. (b) Percentages of c-Fos/5-HT colocalization in the DRN at around $-4.72 \mathrm{~mm}$ from bregma. LY34I 495 (0.03 pmol/side) or ketamine ( $3 \mathrm{nmol} / \mathrm{side})$ was administered into the $\mathrm{mPFC} 90 \mathrm{~min}$ before the test. NBQX $(0.03 \mathrm{nmol} / \mathrm{side})$ was administered into the mPFC $95 \mathrm{~min}$ before the test. No differences in the number of single 5-HT-positive cells in the DRN were observed between groups ((b): $n=43.8 \pm 2.9$ (vehicle), $53.8 \pm 9.8$ (LY34I495), $46.8 \pm 5.5$ (ketamine), $58.7 \pm 9.1$ (NBQX)). Vehicle: Ringer's solution. Values indicate the mean \pm SEM $(n=6)$. *** $P<0.00$ I compared with vehicle (Student's $t$-test).

microinjection of NBQX $(0.03 \mathrm{nmol} / 0.1 \mu \mathrm{l} /$ side $)$ into the $\operatorname{mPFC}(F(3,30)=10.67, p<0.001$; Figure 3d). Similarly, the decrease in the immobility time induced by systemic administration of ketamine $(30 \mathrm{mg} / \mathrm{kg}$ i.p.) was also blocked by microinjection of NBQX $(0.03 \mathrm{nmol} / 0.1 \mu \mathrm{l} /$ side $)$ into the $\operatorname{mPFC}(\mathrm{F}(3,26)=10.04, p<0.01$; Figure 3e). In contrast, microinjection of NBQX $(0.03 \mathrm{nmol} / 0.1 \mu \mathrm{l} / \mathrm{side})$ into the mPFC per se had no effect on the immobility time in the FST $(\mathrm{F}(1,13)<0.01, p=0.96$; Figure $3 \mathrm{f})$. Figure $3 \mathrm{~g}$ and $\mathrm{h}$ show the locations of the tips of the microinjection cannulas in the mPFC included in the analysis of the data shown in Figure $3 \mathrm{~d}-\mathrm{f}$, respectively, that were included in the statistical analyses.

\section{Effect of Microinjection of LY341495 or Ketamine into the mPFC on the c-Fos Immunoreactivity of 5-HT Neurons in the DRN}

Microinjection of LY341494 (0.03 pmol/0.1 $\mu \mathrm{l} / \mathrm{side})$ into the mPFC significantly increased the percentage of 5-HT cell bodies in the DRN exhibiting c-Fos immunoreactivity $(\mathrm{F}(1,10)=24.01, \quad p<0.001 ; \quad$ Figure $4 \mathrm{a}$ and $\mathrm{b}$ and Supplementary Figure S4). Microinjection of ketamine ( $3 \mathrm{nmol} / 0.1 \mu \mathrm{l} / \mathrm{side}$ ) into the $\mathrm{mPFC}$ also significantly increased the percentage of $5-\mathrm{HT}$ cell bodies in the DRN showing c-Fos immunoreactivity $(\mathrm{F}(1,10)=25.80$, $p<0.001$; Figure 4a and b and Supplementary Figure S4). In contrast, microinjection of NBQX $(0.03 \mathrm{nmol} / 0.1 \mu \mathrm{l} / \mathrm{side})$ into the mPFC had no effect on the percentage of 5-HT cell bodies in the DRN showing c-Fos immunoreactivity $(\mathrm{F}(1,10)=0.18, p=0.68$; Figure $4 \mathrm{a}$ and $\mathrm{b}$ and Supplementary Figure S4). These results are summarized in Supplementary Table S2.

\section{Effect of Microinjection of an AMPA Receptor} Antagonist on LY341495 or Ketamine-Induced Increase of the c-Fos Immunoreactivity of 5-HT Neurons in the DRN

Systemic administration of LY341494 (1 mg/kg i.p.) significantly increased the percentage of 5-HT cell bodies in the DRN exhibiting c-Fos immunoreactivity $(F(2,15)=17.97$, $p<0.001$; Figure $5 \mathrm{a}$ and $\mathrm{c}$ and Supplementary Figure S5a). This increase in c-Fos immunoreactivity in the 5-HT neurons was blocked by prior microinjection of NBQX $(0.03 \mathrm{nmol} / 0.1 \mu \mathrm{l} / \mathrm{side})$ into the $\operatorname{mPFC}(\mathrm{F}(2,15)=17.97$, $p<0.001$; Figure 5a and $c$ and Supplementary Figure S5a). Systemic ketamine administration $(30 \mathrm{mg} / \mathrm{kg}$ i.p.) also significantly increased the percentage of 5-HT cell bodies in the DRN exhibiting c-Fos immunoreactivity $(\mathrm{F}(2,15)=10.64, \quad p<0.01$; Figure $5 \mathrm{~b}$ and $\mathrm{d}$ and Supplementary Figure S5b). This increase in the percentage of 5-HT cell bodies in the DRN exhibiting c-Fos immunoreactivity was blocked by prior microinjection of NBQX $(0.03 \mathrm{nmol} / 0.1 \mu \mathrm{l} / \mathrm{side})$ into the $\operatorname{mPFC}(\mathrm{F}(2,15)=10.64$, $p<0.01$; Figure $5 \mathrm{~b}$ and d,Supplementary Figure S5b). These results are summarized in Supplementary Table S2. 
a
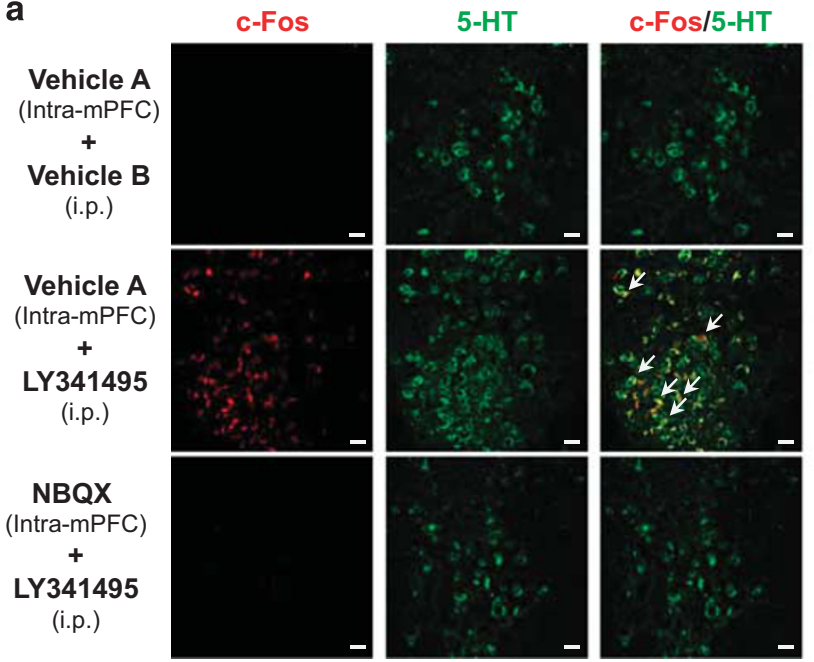

b

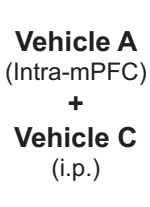

Vehicle A (Intra-mPFC) $+$
Ketamine
(i.p.)

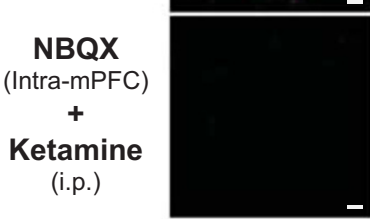

$(40 x)$
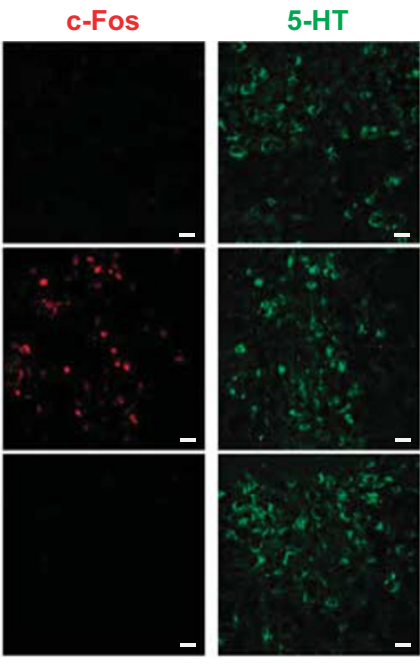

c-Fos/5-HT

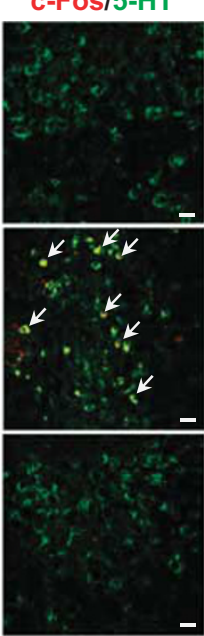

$(40 x)$
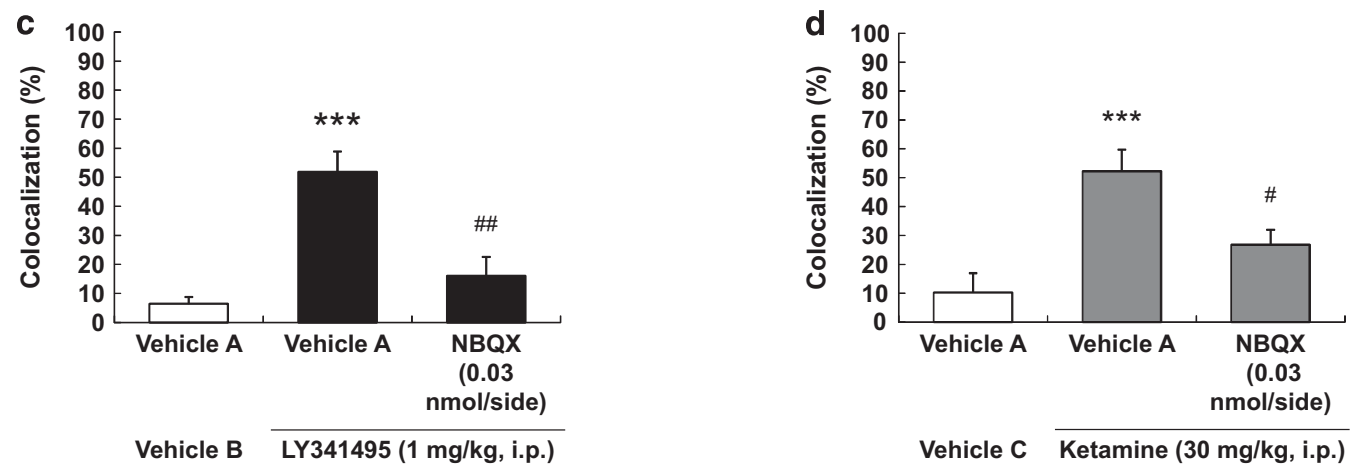

Figure 5 Effect of microinjection of an AMPA receptor antagonist on LY34I495- or ketamine-induced c-Fos immunoreactivity colocalized with 5-HT neuron cells in the dorsal raphe nucleus. (a, b) Confocal images of c-Fos (red), 5-HT cells (green), and double (5-HT/c-Fos, colocalization) immunoreactivities in the DRN at around $-4.72 \mathrm{~mm}$ from bregma (Scale bar: (a, b) $20 \mu \mathrm{m}$ ). Arrows represent the double (5-HT/c-Fos, colocalization) immunoreactivities. (c, d) Percentages of c-Fos/5-HT colocalization in the DRN at around $-4.72 \mathrm{~mm}$ from bregma following LY34I495 (c) or ketamine (d) administration. LY34I495 (I mg/kg i.p.) or ketamine (30 mg/kg, i.p.) was administered $90 \mathrm{~min}$ before the test. NBQX (0.03 nmol/side) was administered into the mPFC $95 \mathrm{~min}$ before the test. No differences in the number of single 5-HT-positive cells in the DRN were observed between groups ((c): $n=59.5 \pm 10.1$ (vehicle A-treated vehicle B), $81.3 \pm 17.7$ (vehicle A-treated LY34I495), $67.5 \pm 11.3$ (NBQX-treated LY34I 495); (d): $n=84.2 \pm 8.3$ (vehicle A-treated vehicle C),

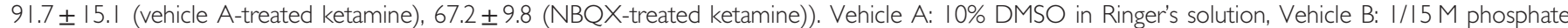
buffer $(\mathrm{pH}$ 8.0), Vehicle $\mathrm{C}$ : saline. Values indicate the mean \pm SEM $((\mathrm{c}): n=6,(d): n=6) . * * * P<0.00$ I compared with vehicle A-treated each vehicles

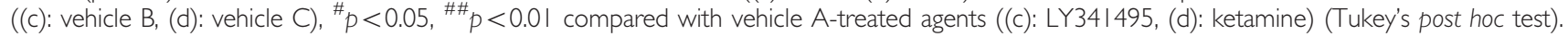

\section{DISCUSSION}

In the present study, we demonstrated, for the first time, that an mGlu2/3 receptor antagonist and ketamine activated a subset of 5-HT neurons in the DRN, presumably through AMPA receptor stimulation in the mPFC, and that this mechanism may be involved in the antidepressant effects of the two compounds.

First, we investigated the involvement of the 5-HTergic systems in the antidepressant effects of an mGlu2/3 receptor antagonist, LY341495, and ketamine in the FST. The antidepressant effects of LY341495 and ketamine were blocked by depletion of 5-HT by pretreatment with a tryptophan hydroxylase inhibitor, PCPA. Previously, we reported that the actions of an $\mathrm{mGlu} 2 / 3$ receptor antagonist and ketamine were attenuated by pretreatment with PCPA in the NSFT (Fukumoto et al, 2014). Therefore, the 5-HTergic systems may play a key role in the antidepressant effects of the $\mathrm{mGlu} 2 / 3$ receptor antagonists and ketamine. Moreover, the sustained antidepressant effects of LY341495 and ketamine, which were observed even at $24 \mathrm{~h}$ after the treatment, were also attenuated by pretreatment with PCPA, suggesting that the 5 -HTergic systems may also be involved in the sustained antidepressant effects of the mGlu2/3 receptor antagonist and ketamine in the FST. On the other hand, paroxetine did not exert the sustained antidepressant effect, suggesting that the mode of action on 5-HTergic systems is different between the mGlu2/3 receptor antagonist and ketamine and paroxetine. Of note, we have confirmed previously that the present treatment condition is sufficient for the pharmacological depletion of 5-HT in mice (Fukumoto et al, 2014). Contrary to our findings, it has been reported that the acute antidepressant effects of ketamine and an mGlu2/3 receptor antagonist in the FST and tail suspension test, respectively, were independent of the 5-HTergic systems (Gigliucci et al, 2013; 
Pałucha-Poniewiera et al, 2010). Although these differences may be ascribed to differences in the study paradigms or conditions among the studies, the precise reason remains unclear at present.

An $\mathrm{mGlu} 2 / 3$ receptor antagonist and ketamine have been reported to exert antidepressant effects via their actions on the mPFC (Dwyer et al, 2012; Li et al, 2010), where both compounds increase synaptic protein synthesis through BDNF-mTOR signaling pathways. Therefore, we investigated the effects of microinjection of LY341495 and ketamine into the $\mathrm{mPFC}$ in the FST, and the involvement of the 5-HTergic systems in these effects. In this study, microinjection of LY341495 and ketamine into the mPFC exhibited antidepressant effects in the FST without affecting the locomotor activities, and these effects were attenuated by pretreatment with PCPA. Therefore, the antidepressant effects of the mGlu2/3 receptor antagonist and ketamine appeared to be exerted by modulation of the 5-HTergic neurons through their actions on the mPFC. Moreover, the antidepressant effects of microinjection of LY341495 and ketamine into the $\mathrm{mPFC}$ lasted for $24 \mathrm{~h}$ after the treatment in the FST, indicating that actions of these compounds in the $\mathrm{mPFC}$ are involved in the sustained antidepressant effects.

Next, we investigated the neural mechanisms by which the two compounds regulate the 5-HTergic systems through their actions on the mPFC to exert antidepressant effects. The DRN contains the majority of the 5-HT neurons in the brain that are regulated by neural projections from various brain regions, including the PFC (Pollak Dorocic et al, 2014). Stimulation of the AMPA receptor expressed on the pyramidal neurons in the $\mathrm{mPFC}$ projecting to the $\mathrm{DRN}$ has been reported to activate the 5-HT neurons in the DRN (Martín-Ruiz et al, 2001), and AMPA receptor stimulation has been shown to be involved in the antidepressant effects as well as increase in 5 -HT release in the $\mathrm{mPFC}$ by both mGlu2/3 receptor antagonists and ketamine (Karasawa et al, 2005; Koike et al, 2011a, b; Maeng et al, 2008; Nishitani et al, 2014). Given that LY341495 and ketamine reportedly increase the release of glutamate in the PFC, presumably through inhibition of the autoreceptor in the glutamatergic nerve terminals for the case of LY341495 (Hascup et al, 2010) and disinhibition of pyramidal neurons in the PFC for the case of ketamine (Moghaddam et al, 1997), it is conceivable that both the mGlu2/3 receptor antagonist and ketamine activate postsynaptic AMPA receptor in the mPFC through enhancing the release of glutamate that may lead to subsequent activation of the 5-HTergic systems to exert antidepressant effects. To verify this hypothesis, we first investigated the involvement of the AMPA receptor in the $\mathrm{mPFC}$ in the antidepressant effects of the mGlu2/3 receptor antagonist and ketamine. We confirmed that the antidepressant effects of LY341495 and ketamine were abolished by pretreatment with systemic administration of an AMPA receptor antagonist, NBQX, in the present condition as previously reported (Koike et al, 2011a, b; Maeng et al, 2008; Pałucha-Poniewiera et al, 2010). Moreover, the antidepressant effects of LY341495 and ketamine were also blocked by microinjection of NBQX into the mPFC. Therefore, it can be concluded that stimulation of the AMPA receptor in the $\mathrm{mPFC}$ is involved in the antidepressant effects of the mGlu2/3 receptor antagonist and ketamine in the FST.
Then, we employed immunohistochemistry to determine whether the antidepressant effects of LY341495 and ketamine mediated by activation of the AMPA receptor in the MPFC may also be associated with activation of the 5-HT neurons in the DRN. Microinjection of LY341495 and ketamine into the mPFC increased c-Fos immunoreactivity in the 5-HT neurons in the DRN. These results suggest that the $\mathrm{mGlu} 2 / 3$ receptor antagonist and ketamine activated the 5-HT neurons in the DRN through their actions in the mPFC. Furthermore, systemic administration of LY341495 and ketamine also increased c-Fos immunoreactivity in the 5-HT neurons in the DRN that were blocked by microinjection of NBQX into the mPFC. Therefore, it was concluded that the $\mathrm{mGlu} 2 / 3$ receptor antagonist and ketamine induced activation of the 5-HT neurons in the DRN through stimulation of AMPA receptor in the $\mathrm{MPFC}$. Taken together, the findings suggest that activation of a subset of 5-HT neurons in the DRN modulated by stimulation of the AMPA receptor in the $\mathrm{mPFC}$ may be involved in the antidepressant effects of the mGlu2/3 receptor antagonist and ketamine. Some previous reports also lend support to this notion. Recently, it was reported that antidepressant effects could be obtained in the rats by selective stimulation, using an optogenetic technique, of the neurons in the $\mathrm{DRN}$ regulated by $\mathrm{mPFC}$ projections, whereas no such effect was obtained following activation of the entire population of DRN neurons (Warden et al, 2012). Another report indicated that DBS of the mPFC yielded antidepressant effects, which was abolished by 5-HT depletion (Hamani et al, 2010). These reports suggest that 5-HTergic systems selectively modulated by mPFC-DRN projections may be involved in the antidepressant effects. In contrast, a previous study reported that excitatory ventromedial PFC (vmPFC) projections were primarily localized in the GABA-rich areas of the DRN, and that optogenetic activation of the vmPFC terminals in the DRN increased c-Fos expression in the GABA neurons to a great extent than that in the 5-HT neurons (Challis et al, 2014), consistent with the previously reported findings that the $\mathrm{mPFC}$ projections to the DRN preferentially target local-circuit GABAergic neurons (Jankowski and Sesack, 2004; Varga et al, 2003; Wang et al, 1992). These differences may be because of the differences in the population of neurons in the DRN modulated by mPFC projections. Recently, identification of monosynaptic glutamatergic inputs from the PFC to 5-HTergic neurons in the DRN was reported (Pollak Dorocic et al, 2014), indicating that the direct PFC-DRN pathway that exerts excitatory control over 5-HTergic neurons in the DRN exists. Moreover, the other group has reported that the PFC preferentially innervates the 5-HT neurons over the GABA neurons in the DRN, and that cortical axon photoactivation was twice as efficient at triggering EPSCs in the 5-HT neurons than in the GABA neurons (Weissbourd et al, 2014), indicating, as observed in the present study, that a part of the mPFC projections may preferentially activate the $5-\mathrm{HT}$ neurons in the DRN. It should be noted, however, that one of the limitations of the present study is that we used only FST, and the present findings should be confirmed in other animal models of depression in future studies.

In conclusion, we provide evidence, for the first time, that the antidepressant effects of an mGlu2/3 receptor antagonist and ketamine may be mediated by the activation of a subset 
of 5-HT neurons in the DRN modulated by stimulation of the AMPA receptor in the $\mathrm{mPFC}$. Therefore, the present findings provide an understanding of the neural mechanisms underlying the antidepressant effects of the mGlu2/3 receptor antagonists and ketamine, and further investigation may pave the way for innovative therapies for the treatment of major depressive disorder. Moreover, given that mGlu2/3 receptor antagonists share the similar mechanisms of action with ketamine, yet they did not show undesirable side effects in humans (Gradient et al, 2012), mGlu2/3 receptor antagonists could be alternatives to ketamine.

\section{FUNDING AND DISCLOSURE}

The authors declare no conflict of interest. Kenichi Fukumoto, Michihiko Iijima, and Shigeyuki Chaki are employees of Taisho Pharmaceutical.

\section{ACKNOWLEDGMENTS}

We thank Drs Takao Yoshimizu and Daiji Kambe for technical advice for immunohistochemical studies.

\section{REFERENCES}

Ago Y, Yano K, Araki R, Hiramatsu N, Kita Y, Kawasaki T et al (2013). Metabotropic glutamate $2 / 3$ receptor antagonists improve behavioral and prefrontal dopaminergic alterations in the chronic corticosterone-induced depression model in mice. Neuropharmacology 65: 29-38.

Autry AE, Adachi M, Nosyreva E, Na ES, Los MF, Cheng PF et al (2011). NMDA receptor blockade at rest triggers rapid behavioural antidepressant responses. Nature 475: 91-95.

Berman RM, Cappiello A, Anand A, Oren DA, Heninger GR, Charney DS (2000). Antidepressant effects of ketamine in depressed patients. Biol Psychiatry 47: 351-354.

Chaki S, Yoshikawa R, Hirota S, Shimazaki T, Maeda M, Kawashima N et al (2004). MGS0039: a potent and selective group II metabotropic glutamate receptor antagonist with antidepressant like activity. Neuropharmacology 46: 457-467.

Challis C, Beck SG, Berton O (2014). Optogenetic modulation of descending prefrontocortical inputs to the dorsal raphe bidirectionally bias socioaffective choices after social defeat. Front Behav Neurosci 8: 43.

Dwyer JM, Lepack AE, Duman RS (2012). mTOR activation is required for the antidepressant effects of mGluR2/3 blockade. Int J Neuropsychopharmacol 15: 429-434.

Dwyer JM, Lepack AE, Duman RS (2013). mGluR2/3 blockade produces rapid and long-lasting reversal of anhedonia caused by chronic stress exposure. J Mol Psychiatry 1: 15.

Fukumoto K, Iijima M, Chaki S (2014). Serotonin-1A receptor stimulation mediates effects of a metabotropic glutamate 2/3 receptor antagonist, 2S-2-amino-2-(1S,2S-2-carboxycycloprop-1-yl)-3-(xanth-9-yl)propanoic acid (LY341495), and an $\mathrm{N}$-methyl-D-aspartate receptor antagonist, ketamine, in the novelty-suppressed feeding test. Psychopharmacology (Berl) 2231: 2291-2298.

Gigliucci V, O'Dowd G, Casey S, Egan D, Gibney S, Harkin A (2013). Ketamine elicits sustained antidepressant-like activity via a serotonin-dependent mechanism. Psychopharmacology (Berl) 228: $157-166$.

Gradient RA, Wedel PC, Frisbie VM, Leuchter AF, Targum SD, Truong CT et al (2012). Safety, pharmacokinetic and pharmacodynamics profile of BCI-632, a selective metabotropic glutamate
2/3 receptor antagonist, in healthy human subjects. Abstr Neurosci Meeting 42: 20.

Hamani C, Diwan M, Macedo CE, Brandão ML, Shumake J, Gonzalez-Lima F et al (2010). Antidepressant-like effects of medial prefrontal cortex deep brain stimulation in rats. Biol Psychiatry 67: 117-124.

Hascup ER, Hascup KN, Stephens M, Pomerleau F, Huettl P, Gratton A et al (2010). Rapid microelectrode measurements and the origin and regulation of extracellular glutamate in rat prefrontal cortex. J Neurochem 115: 1608-1620.

Ibrahim L, Diazgranados N, Luckenbaugh DA, Machado-Vieira R, Baumann J, Mallinger AG et al (2011). Rapid decrease in depressive symptoms with an N-methyl-d-aspartate antagonist in ECT-resistant major depression. Prog Neuropsychopharmacol Biol Psychiatry 35: 1155-1159.

Iijima M, Koike H, Chaki S (2013). Effect of an mGlu2/3 receptor antagonist on depressive behavior induced by withdrawal from chronic treatment with methamphetamine. Behav Brain Res 246: 24-28.

Jankowski MP, Sesack SR (2004). Prefrontal cortical projections to the rat dorsal raphe nucleus: ultrastructural features and associations with serotonin and gamma-aminobutyric acid neurons. J Comp Neurol 468: 518-529.

Karasawa J, Shimazaki T, Kawashima N, Chaki S (2005). AMPA receptor stimulation mediates the antidepressant-like effect of a group II metabotropic glutamate receptor antagonist. Brain Res 1042: 92-98.

Kawashima N, Karasawa J, Shimazaki T, Chaki S, Okuyama S, Yasuhara A et al (2005). Neuropharmacological profiles of antagonists of group II metabotropic glutamate receptors. Neurosci Lett 378: 131-134.

Koike H, Iijima M, Chaki S (2011a). Involvement of the mammalian target of rapamycin signaling in the antidepressant-like effect of group II metabotropic glutamate receptor antagonists. Neuropharmacology 61: 1419-1423.

Koike H, Iijima M, Chaki S (2011b). Involvement of AMPA receptor in both the rapid and sustained antidepressant-like effects of ketamine in animal models of depression. Behav Brain Res 224: 107-111.

Koike H, Iijima M, Chaki S (2013a). Effects of ketamine and LY341495 on the depressive-like behavior of repeated corticosterone-injected rats. Pharmacol Biochem Behav 107: $20-23$.

Koike H, Fukumoto K, Iijima M, Chaki S (2013b). Role of $\mathrm{BDNF} /$ TrkB signaling in antidepressant-like effects of a group II metabotropic glutamate receptor antagonist in animal models of depression. Behav Brain Res 238: 48-52.

Krystal JH, Sanacora G, Duman RS (2013). Rapid-acting glutamatergic antidepressants: the path to ketamine and beyond. Biol Psychiatry 73: 1133-1141.

Li N, Lee B, Liu RJ, Banasr M, Dwyer JM, Iwata M et al (2010). mTOR-dependent synapse formation underlies the rapid antidepressant effects of NMDA antagonists. Science 329: 959-964.

López-Gil X, Babot Z, Amargós-Bosch M, Suñol C, Artigas F, Adell A (2007). Clozapine and haloperidol differently suppress the MK-801-increased glutamatergic and serotonergic transmission in the medial prefrontal cortex of the rat. Neuropsychopharmacology 32: 2087-2097.

López-Gil X, Jiménez-Sánchez L, Romón T, Campa L, Artigas F, Adell A (2012). Importance of inter-hemispheric prefrontal connection in the effects of non-competitive NMDA receptor antagonists. Int J Neuropsychopharmacol 15: 945-956.

Maeng S, Zarate CA Jr, Du J, Schloesser RJ, McCammon J, Chen G (2008). Cellular mechanisms underlying the antidepressant effects of ketamine: role of alpha-amino-3hydroxy-5-methylisoxazole-4-propionic acid receptors. Biol Psychiatry 63: 349-352. 
Martín-Ruiz R, Puig MV, Celada P, Shapiro DA, Roth BL, Mengod G et al (2001). Control of serotonergic function in medial prefrontal cortex by serotonin-2A receptors through a glutamate-dependent mechanism. J Neurosci 21: 9856-9866.

Moghaddam B, Adams B, Verma A, Daly D (1997). Activation of glutamatergic neurotransmission by ketamine: a novel step in the pathway from NMDA receptor blockade to dopaminergic and cognitive disruptions associated with the prefrontal cortex. J Neurosci 17: 2921-2927.

Nishitani N, Nagayasu K, Asaoka N, Yamashiro M, Shirakawa H, Nakagawa T et al (2014). Raphe AMPA receptors and nicotinic acetylcholine receptors mediate ketamine-induced serotonin release in the rat prefrontal cortex. Int J Neuropsychopharmacol 17: 1321-1326.

Nowak K, Meyza K, Nikolaev E, Hunt MJ, Kasicki S (2012). Local blockade of NMDA receptors in the rat prefrontal cortex increases c-Fos expression in multiple subcortical regions. Acta Neurobiol Exp (Wars) 72: 207-218.

Pałucha-Poniewiera A, Wierońska JM, Brański P, Stachowicz K, Chaki S, Pilc A (2010). On the mechanism of the antidepressant-like action of group II mGlu receptor antagonist, MGS0039. Psychopharmacology (Berl) 212: 523-535.

Paxinos G, Franklin K (1997). The mouse brain in stereotaxic coordinates. Academic, San Diego.

Pollak Dorocic I, Fürth D, Xuan Y, Johansson Y, Pozzi L, Silberberg G et al (2014). A whole-brain atlas of inputs to serotonergic neurons of the dorsal and median raphe nuclei. Neuron 83: 663-678.
Sugimoto Y, Yamamoto M, Tagawa N, Kobayashi Y, Mitsui-Saitoh K, Hotta Y et al (2011). Differences between mice strains in response to paroxetine in the forced swimming test: involvement of serotonergic or noradrenergic systems. Eur J Pharmacol 672: 121-125.

Varga V, Kocsis B, Sharp T (2003). Electrophysiological evidence for convergence of inputs from the medial prefrontal cortex and lateral habenula on single neurons in the dorsal raphe nucleus. Eur J Neurosci 17: 280-286.

Wang QP, Ochiai H, Nakai Y (1992). GABAergic innervation of serotonergic neurons in the dorsal raphe nucleus of the rat studied by electron microscopy double immunostaining. Brain Res Bull 29: 943-948.

Warden MR, Selimbeyoglu A, Mirzabekov JJ, Lo M, Thompson KR, Kim SY et al (2012). A prefrontal cortex-brainstem neuronal projection that controls response to behavioural challenge. Nature 492: $428-432$.

Weissbourd B, Ren J, DeLoach KE, Guenthner CJ, Miyamichi K, Luo L (2014). Presynaptic partners of dorsal raphe serotonergic and GABAergic neurons. Neuron 83: 645-662.

Yamanaka H, Yokoyama C, Mizuma H, Kurai S, Finnema SJ, Halldin C et al (2014). A possible mechanism of the nucleus accumbens and ventral pallidum 5-HT1B receptors underlying the antidepressant action of ketamine: a PET study with macaques. Transl Psychiatry 4: e342.

Zarate CA Jr, Singh JB, Carlson PJ, Brutsche NE, Ameli R, Luckenbaugh DA (2006). A randomized trial of an N-methyl-Daspartate antagonist in treatment-resistant major depression. Arch Gen Psychiatry 63: 856-864.

Supplementary Information accompanies the paper on the Neuropsychopharmacology website (http://www.nature.com/npp) 